\title{
整
}

\section{Oud en Nieuw Verbond: contingentie en coherentie in de verbondsgeschiedenis}

\author{
B.Wielenga \\ Gereformeerde Zending \\ RICHMOND (KZN) \\ E-pos: bob.wielenga@pixie co.za
}

\begin{abstract}
Old and New Covenant: contingency and coherence in the history of the covenant

In this article the relationship between the different covenants in the Old and New Testament is discussed. This relationship is described as an interrelationship between the different phases of the history of the covenant, applying contingency and coherence (see Beker, 1980) as terms which adequately describe the historical nature of the covenant. The conclusion arrived at is that the one and same covenant of grace throughout its whole history is characterized by contingency and coherence, which prevents one from contrasting the Old and New Covenant as is usually done in the tradition of Reformed theology. Each phase of the history of the covenant has its own characteristics which are historically determined, but which at the same time transmit an eternal message of salvation.
\end{abstract}

\section{Inleiding}

In deze bijdrage willen wij een onderwerp aan de orde stellen dat van meet aan in de gereformeerde traditie een centrale rol heeft gespeeld, en dat nog altijd niets aan actualiteit heeft ingeboet. In tegenstelling met de Lutherse Reformatie (zie Obermann, 1986:107 e.v.) werd in de strijd om de handhaving van de kinderdoop tegen doperse radikalen (Balke, 1973) door Reformatoren als Zwingli, Bullinger en Calvijn (Graafland, 1992) de eenheid tussen Oud en Nieuw Verbond met klem naar voren gebracht (Verboom, 1996; De Greef, 1996). Zo kon ook opgekomen worden voor het blijvende gezag van het Oude Testament als Woord van God. Wij willen nagaan hoe er in het Oude Testament over het Nieuwe Verbond wordt gesproken en hoe zich dat verhoudt tot wat wij in de brief aan de Hebreeën daarover lezen. Natuurlijk zouden in verband met deze thematiek allerlei praealabele vragen moeten worden beantwoord die verband houden met 
hermeneutiek en methodiek. Maar behandeling van deze vóórvragen zou een artikel apart vragen (vgl. Wielenga, 1994); wij willen echter gelijk zur Sache komen, waarbij we het risiko nemen dat een aantal vragen onbehandeld en onbeantwoord blijft. Wij kiezen er ook voor om thetisch onze eigen gedachtengang te ontwikkelen zonder de discussie aan te gaan met andere onderzoekstradities; een artikel over zo 'n breed onderwerp als deze moet zich beperken.

Ook gaan we voorbij aan de discussie over de betekenis van de term verbond, waarover in de moderne bijbelwetenschap grondig van mening wordt verschild (Nicholson, 1986). Wij volgen in grote lijnen Eichrodt (1957; 1961), Vriezen (1966) en McCarthy $(1972 ; 1978 ; 1985)$. We gaan in deze studie als werkhypothese ervan uit dat het verbond een werkelijke relatie aanduidt tussen God en mensen, die unilateraal door Hem is aangegaan, bilateraal door Hem wordt onderhouden, en forensisch door Hem is gefundeerd. Het gaat om een wederkerige verhouding, die asymetrisch van structuur is en eschatologisch gericht. Met Kalluveettil (1982) zijn we van mening dat we niet alleen dat tekstmateriaal moeten onderzoeken waar de term expressis verbis voorkomt, maar dat ons onderzoek niet voorbij moet gaan aan die plaatsen waar de zaak voorkomt waar het in de term omgaat. We kunnen dan ook onmogelijk pas beginnen in Genesis 6:18, waar voor het eerst de term verbond voorkomt; al in Genesis 1 e.v. komt zakelijk het verbond ter sprake (vgl. Wielenga, 1996a). Wij zijn ook van oordeel dat het genadeverbond niet pas bij Abraham begonnen is (contra Van Rooy, 1996:78 e.v.), maar als gunstverbond met Adam in het paradijs werd gesloten (De Graaf, 1954) en na de zondeval als genadeverbond werd voortgezet (Wielenga, 1996a), terwijl ook het Noachitische verbond tot de geschiedenis van het genadeverbond moet worden gerekend (Wielenga, 1996b). Het spreken over een werkverbond moet als een dogmatisch misverstaan van de Schrift worden vermeden (Oosterhoff, 1972).

Een belangrijke vraag waar wij wel op in zullen gaan, is die naar de relatie tussen de verschillende fasen van de ene verbondsgeschiedenis gedurende de oudtestamentische periode. Uit de dogmatiek is de tegenstelling bekend tussen het verbond met Abraham gesloten en dat met Israel op Horeb (zie Konig, 1987:94 e.v.). Volgens deze opvatting is het Nieuwe Verbond identiek met het Abrahamitische, terwijl dan het Oude Verbond, dat door het Nieuwe werd vervangen, gelijkgesteld moet worden met het zogenaamde Horeb-verbond. Zo meent men recht te doen aan wat Paulus over de wet schrijft in zijn brieven, en met name aan wat in de brief aan de Hebreeën over Oud en Nieuw Verbond wordt gezegd. Vrij algemeen is men in de modernere bijbelwetenschap van oordeel dat in het Nieuwe Testament geen recht gedaan wordt aan het oudtestamentische Schriftgetuigenis over het Nieuwe Verbond (Luz, 1967; Lehne, 1990). De discontinuiteit tussen Oud en Nieuw Verbond wordt zo benadrukt. In onze bijdrage willen wij deze discontinuiteit niet ontkennen; we 
zullen echter betogen dat zij in dienst staat van de continuiteit tussen Oud en Nieuw Verbond. Vandaar dat wij de termen contingentie en coherentie - ontleend aan Beker (1980) - gebruiken om deze spanningsvolle relatie tussen Oud en Nieuw Verbond te omschrijven. Er is coherentie in de ene verbondsgeschiedenis, zoals beschreven in de Schrift. In de gereformeerde traditie werd dat omschreven met. er is eenheid in substantie tussen de verbonden, d.w.z. het gaat over het ene en zelfde heil. Tegelijk moet de contingentie in rekening worden gebracht: het ene verbond doorloopt een geschiedenis, waarin breuklijnen, veroorzaakt door de zondige ontrouw van Israel, voorkomen, waardoor ook iedere fase een eigen historische identiteit gekregen heeft. De gereformeerde vaderen spraken dan over het verschil in administratie tussen de verbonden, een minder gelukkige term omdat de historiciteit van het verbond er niet voldoende door wordt uitgedrukt.

Vanuit deze interesse in de samenhang tussen Oud en Nieuw Verbond in beide Testamenten gaan we in op de aard van het op Horeb met Israel gesloten verbond: mag dat een genadeverbond genoemd worden of staat het ook in het Oude Testament tegenover het Abrahamitische verbond? In het kader van het Mozaissche verbond gaan we kort in op de plaats van het Davidische verbond: 2 Samuel 7. Het profetische spreken over het Nieuwe Verbond zal dan worden onderzocht, waarna we in zullen gaan op wat de Hebreeënbrief over het Oude Verbond schrijft. Wij beseffen dat een artikel te weinig ruimte biedt voor een grondige behandeling van het bijbelse materiaal; veel zal ongezegd moeten blijven of bekend worden verondersteld. We hopen echter een bijdrage te leveren aan de doordenking van een actueel thema uit de gereformeerde theologie, dat ook prof. Van Rooy's aandacht altijd heeft geboeid.

\section{Het Mozaische verbond als genadeverbond}

In de Gereformeerde Orthodoxie (Graafland, 1996:30) werd sinds Ursinus, Olevianus en Perkins het op Horeb met Israel gesloten verbond vooral in de slagschaduw van het werkverbond geplaatst, waardoor aan het spreken van de Schrift zelf geen recht gedaan kon worden. Het werkverbond was een meritoriaal gestructureerd verbond met Adam vóór de zondeval gesloten, wat erop neerkwam dat hij het eeuwig leven kon verdienen door het houden van de lex naturae (Verboom, 1996:380 e.v.). Dit werkverbond heeft God opnieuw aan Israel voorgesteld via Mozes; de Decaloog werd gezien als een herziene vorm van de praelapsarische lex naturae, waaraan Israel moest voldoen om het heil te beërven. De eis der wet bleef gehandhaafd, waarop het verbond wel moest stuk lopen. Het Oude Verbond dreef Israel uit naar de beloofde messias; heilshistorisch is het Oude Verbond dan wel achterhaald door het Nieuwe Verbond, heilsordelijk blijft de wet deze naar Christus uitdrijvende funktie behouden (Graafland, 1994:159 e.v.). Duidelijk kan zo het Oude Verbond geen genadeverbond heten. Vandaar dat men van overtuiging is dat daarom in het Nieuwe 
Testament het verbond met Abraham als het eigenlijke genadeverbond gezien wordt. Wij willen betogen dat de tekst van de Schrift zelf deze theologische constructie niet ondersteunt en dat zij juist een andere richting uitwijst, waarin meer recht gedaan kan worden aan de eenheid van de canonieke Schrift op dit punt.

\subsection{Het verbond met Abraham}

Het verbond met Abraham was Gods reaktie op de krisis van het verbond met Noach in Babel (Genesis 11). De roeping van de heiden Abram, Genesis 12, markeert het begin van een nieuwe fase in de geschiedenis van het verbond van God met mensen, dat herinneringen oproept aan de schepping in Genesis 1. De verbondsgeschiedenis die met Adam een aanvang nam, werd zo door God soeverein op gang gehouden tot heil en zegen van de wereld, waar de beloften aan Abram in Genesis 12:1-3 van getuigen. Ondanks de breuklijn in de verbondsgeschiedenis, veroorzaakt door de "zondeval" in Babel, zette God zijn heilsplan door. Er is discontinuiteit met de voorafgaande fase die met Noach begon: er vond van nu af aan concentratie plaats op één persoon en volk in éen land, maar het was wel ten dienste van de hele wereld; de beloften aan Noach, ook die met het oog op de schepping, werden in de nieuwe verbondsfase gehandhaafd (Wielenga, 1996b). Dat het verbond met Abraham dat door God unilateraal tot stand werd gebracht, door Hem bilateraal wordt onderhouden, kan blijken uit de van Abraham verwachte gehoorzaamheid (Genesis 22). De forensische fundering van het verbond kan afgelezen worden uit de opdracht tot besnijdenis (Genesis 17) als verbondssacrament.

In de oudtestamentische tradities wordt er ook regelmatig op het verbond met Abraham teruggekomen. Maar nooit wordt het dan gecontrasteerd met het Mozaïsche verbond. Te denken valt bij voorbeeld aan Jesaja 41:8; 51:2;54:1 en 63:16 (zie Koole, 1985; 1990; 1995). In deze profetische teksten liggen beide verbonden in elkaars verlengde als twee op elkaar volgende fasen van het ene en zelfde genadeverbond. Dat juist in de ballingschapssituatie op de Abrahamtraditie werd teruggegrepen, laat zich verklaren uit pastorale motieven. De ontmoedigde ballingen werden zo bemoedigd aan hun vertrouwen in de God van Abraham vast te houden, want Hij zal zijn aloude beloften gestand doen. Zeker mag er verband gelegd worden tussen het Abrahamitische verbond en de nieuwe heilstoekomst, waar juist in deze Jesaja-tradities over gesproken wordt; zo kan er ook gedacht worden aan een verband van dit verbond met het Nieuwe Verbond, waar dan in Jeremia en Ezechiel expressis verbis over gesproken wordt. Maar nergens is er sprake van een contrast tussen Abraham en Mozes als vertegenwoordigers van twee verschillende soorten verbond, als die van genade tegenover wet (zie Ezechiel 33:23 e.v.). 


\subsection{Het verbond met Mozes}

Rendtorff (1991:129) verwijst terecht naar Exodus 2:24 en 3:6 als verbindende schakel tussen beide verbondsfasen. De beloften aan de patriarchen gedaan, en waarvan er een al in vervulling was gegaan - de belofte van nageslacht - zullen thans vervuld gaan worden, te beginnen met terugkeer naar het land van de belofte. $\mathrm{Na}$ de intocht wordt het op Horeb met Israel in Mozes gesloten verbond vernieuwd in Sichem, een plaats die juist in de Abraham-tradities een belangrijke rol speelt (Genesis 12:6; 33:20; 35:54; Koopmans, 1990:349 e.v.); dat kan niet op toeval berust hebben. Het Abrahamitische verbond gaat een nieuwe fase in. De exodus is Gods soevereine genade-initiatief om de in Egypte vastgelopen verbondsgeschiedenis in beweging te houden naar het door hem gestelde doel: heil en zegen voor de wereld. Dit wordt in een verbondssluiting op Horeb bezegeld (Exodus 24). De vraag of dit verbond een genadeverbond was, kan niet anders dan positief beantwoord worden, verbonden als het was met de uittocht uit Egypte, hèt grote heilsfeit in het Oude Testament. Bovendien moet in rekening gebracht worden dat dit verbond thans alleen nog maar vanuit het perspectief van Exodus 34 kan worden verstaan (Dohmen, 1993:80; Rendtorff, 1991): het verbond, door de afgoderij met het gouden kalf door Israel verbroken, wordt door God wegens Mozes' middelaarschap genadig in stand gehouden en voortgezet. Juist Exodus 34 kwalificeert dit verbond voluit als genadeverbond, dat unilateraal tot stand gebracht en bilateraal in stand gehouden werd.

Het is in dit verband goed te letten op een paar verschillen tussen Exodus 24 en 34 , die ons een beter zicht geven op de aard van dit verbond. Dat het om het zelfde verbond gaat, is buiten kijf voor wie beide hoofdstukken vergelijkt (Dohmen, 1993). Dat ook het in Exodus 34 vemieuwde verbond aansluit op dat met Abraham, kan blijken uit 32:13 en 33:1, waar uitdrukkelijk aan de patriarchale beloften wordt herinnerd. De verschillen hebben van doen met de positie van Mozes in dit verbond. Werd in Exodus 24 het verbond met Israel gesloten, waar Mozes in begrepen was, in hoofdstuk 34 wordt het verbond met Mozes gesloten, in wie het volk begrepen was. In hoofdstuk 24 is het volk, vertegenwoordigd in de oudsten, voluit in de verbondssluiting betrokken; in hoofdstuk 34 is Mozes alleen. Zijn positie als middelaar wordt onderstreept door de genade hem door God bewezen: hij mocht God van zeer nabij ontmoeten, waar de glans op zijn gezicht getuigenis van aflegde (Zenger, 1982:141, 153). Het grote verschil is dat na de zonde met het gouden kalf de genade van God wegens de middelaar wordt geschonken. Deuteronomium 9-10 bevestigt dit. De afstand tussen God en Israel is vergroot, maar tegelijk wordt het verbond vastgemaakt in de middelaar Mozes. De breuk wordt genadig overbrugd.

Dat in dit verbond de vergeving van zonden niet minder centraal stond dan in het in Jeremia 31:31 e.v. aangekondigde Nieuwe Verbond, kan dan ook niet ontkend worden. De cultus, die na de dood van Mozes de verbondsbemiddelende funktie 
toebedeeld kreeg, concentreerde zich in de verzoening van de zondaar, zodat de verbondsrelatie in stand gehouden kon worden; de wet werd geschonken (Wright, 1983:113) niet als "pre-condition of redemption" maar als "protective framework of mutuable responsibilities" in een verbondsraamwerk. De unilaterale en bilaterale structuurelementen van het verbond zijn zo duidelijk herkenbaar, terwijl het bloed van de offers (Exodus 24:8) naar de forensische fundering verwijst. De forensische basis van het verbond is voluit heilscategorisch en gratuitief van aard.

Het is goed kort aandacht te schenken aan de functie van de wet in het kader van dit verbond (Gese, 1977:55-84; Childs, 1993:131 e.v., 533 e.v.). Duidelijk staat de door God gegeven wet in het kader van het genadeverbond. Het is de God, die zich majesteitelijk openbaarde op de Horeb (Zenger, 1982:51), die zijn volk de wet schonk. Het volgt op zijn verlossend handelen in de uittocht (Exodus 19:4-5). Als een aan God toegewijd volk werd Israel de wet gegeven om een koninklijk priesterschap temidden van de volkeren te zijn (19:5-6). Maar geen moment gaat het om de zondaar verbrijzelende functie van de wet. Wie de wet doet, zal daardoor leven (Exodus 34:27 e.v.). In het kader van het Mozaïsche genadeverbond zijn cultus en wet aan elkaar verbonden om Israel in staat te stellen een zegen voor de wereld te zijn in het land der belofte, waardoor Gods belofte aan Abraham vervuld zou kunnen worden (Genesis 12:3). En dat het in de wet om een zaak van het hart gaat, en niet om uiterlijke vormendienst, wordt uit Deuteronomium 30:1-14 wel duidelijk (McCarthy, 1985:363-374). We zullen nog zien dat het verschil tussen dit verbond en het Nieuwe Verbond niet gevonden kan worden in de internalisering van de wet in het hart; dat behoort ook tot de kern van het Mozaissche verbond.

\subsection{Het verbond met David}

Dat het Davidische verbond binnen de perimeters van het Mozaïsche moet worden verstaan, is terecht opgemerkt door McCarthy (1972:403, 411; vgl. Gunneweg, 1960:339; zie ook Wielenga, 1996a:22-25). We gaan verder voorbij aan de discussies over de opkomst van de monarchie in Israel (Mayes, 1978), die veelal gaan over de vraag naar de verhouding tussen de monarchale en antimonarchale tradities in 1 Samuel 7-12. Er was grote huiver om het, als een al te menselijke instelling, in te voeren (Wright, 1983:116 e.v.). Terecht kan gesteld worden dat de roep om een koning als de volkeren rondom er een hadden, de krisis van het Mozaïsche verbond tot een dieptepunt bracht. Gedurende de Richterentijd was deze krisis al hoe duidelijker geworden. Juist aan de figuur van Samuel zien we dat. Menselijk gezien, komt het verbond onder hem tot een hoogtepunt, maar zijn opvolging door zijn zonen brengt de zwakte ervan aan het licht. Terugblikkend wordt dan in het moeilijk te dateren slot van het boek Richteren opgemerkt: er was toen nog geen koning in Israel. En dat geeft al aan dat het koningschap in Israel toch een legitieme plaats ontvangen heeft om de 
verbondskrisis te overwinnen. "The king became the focus of new dimensions of God's self-revelation" (Wright, 1983:118). Met David werd het verbond gesloten, niet om dat met Mozes te vervangen maar om het in vernieuwde vorm voort te zetten, zodat God, trouw aan zijn belofte, in deze weg Israel zou maken tot een zegen voor de volkeren. Juist tegen de achtergrond van de opkomst van het koningschap in Israel en het debacle met Saul kan het verbond met David als voortzetting van het Mozaïsche verbond niet anders dan als genadeverbond getypeerd worden. De genade wordt onderstreept door Gods uitdrukkelijke wens eerst David een huis te bouwen vóór hij aan tempelbouw mag toekomen. Soeverein en genadig hield God het verbondsheft in handen en wordt het koningschap ingezet tot verwerkelijking van zijn heilsplan. Als Davidische monarchie had Israel een koninkrijk van priesters te zijn te midden van de volkeren. De voorwaardelijkheid van dit verbond is er wezenlijk voor en kan niet als deuteronomistische redaktie buiten spel worden gezet (contra Kruse, 1985). David sloot zich juist aan bij het klassieke Jahwisme (Wielenga, 1990:100-111) met haar accent op de Mozaïsche tradities rondom de ark, die juist in Jerusalem een centrale plaats kreeg toebedeeld (2 Samuel 6) in overeenstemming ook met de intenties van Exodus 25. Het Davidische verbond is niet minder voorwaardelijk dan het Mozaiische. Duidelijk is wel dat zo de verbondsgeschiedenis historisch een nieuwe fase inging: van klassiek Jahwisme kwam het tot monarchaal Jahwisme (Wielenga, 1990:100 e.v.). Ondanks deze contingentie is het toch de coherentie die de doorslag geeft in deze ontwikkeling van de Mozaische fase van het genadeverbond. Gods trouw aan zijn verbond staat daar garant voor.

\section{Het Nieuwe Verbond in het Oude Testament}

De verwording van het monarchaal Jahwisme tot nationalistisch Jahwisme, meestal in de literatuur als Zionstheologie aangeduid (Wielenga, 1990:111-121), moet als achtergrond gezien worden van het profetische spreken over het Nieuwe Verbond. De Davididen hadden het verbond vanaf de dagen van Salomo in toenemende mate in de krisis gebracht. Al vanaf de 8ste eeuw werd de profetische kritiek op de monarchie hoorbaar (Wielenga, 1990:111 e.v.): doordat de cultus en de wet werden aangetast onder leiding van de monarchie, kon het verbond ook in zijn monarchale gestalte geen toekomst hebben, ook niet in Juda. Zelfs een koning als Hiskia ontkwam niet aan de kritiek van Jesaja (36-39). Vandaar dat deze profeet al kwam te spreken over een nieuwe Davidide (Jesaja 11:1 e.v.) een volmaakte, Geestbegaafde koning, waar in hoofdstuk 7 al op vooruitgewezen wordt. In Sion, de stad van God, mag rond deze nieuwe koning een nieuwe toekomst worden verwacht voor Israel, waarin de volkeren zullen delen. Vluchtelingen uit Moab zelfs zullen er welkom zijn (Jesaja 16:1 e.v.; zie Wright, 1983:124; Ohmann, 1988:71), een helder bewijs hoe totaal vernieuwd de 
toestand dàn zal zijn. Het verbond zal daarom ook vernieuwd moeten worden om deze krisis te boven te kunnen komen.

In deze traditie staan Jeremia en Ezechiel in hun spreken over het Nieuwe Verbond, waar we nader op in zullen gaan. Maar tevens zal toch in rekening gebracht dienen te worden het spreken over de vroegere en nieuwe dingen in wat dan Deutero-Jesaja wordt genoemd (zie Leene, 1987), en het heilsperspectief van de zogenaamde Trito-Jesaja. De term verbond komt niet altijd ter sprake, maar de categorie van het nieuwe is relevant voor ons verstaan van het Nieuwe Verbond in Oud en Nieuw Testament (Hafemann, 1997).

\subsection{Het Nieuwe Verbond bij Jeremia}

Dat Jeremia 31:31 e.v. niet geîsoleerd van de rest van het boek moet worden uitgelegd, zal niet veel betoog behoeven. Het zou goed zijn te beginnen met aandacht te geven aan hoofdstuk 3:14-18 (Wielenga, 1996a:25-26). Hier treffen we alle elementen van de nieuwe heilstoekomst al aan, die in het Nieuwe Verbond gerealiseerd zullen worden: een situatie waarin een nieuwe Davidide van een totaal ander kaliber zal regeren in de stad van God, en waar de volkeren samen met Israel in het heil zullen delen. De krisis, waarin de Davidide het Mozaische verbond heeft gedompeld (zie Jeremia 17:19-27), zal dan eens en voor goed worden overwonnen. De roep om een nieuw type koning wordt al sterker (23:5). En het zal God zijn die deze zal geven en die in genade zijn verbond door hem vernieuwd zal voortzetten (zie 30:9; cf. Schenker, 1993:107 e.v.). Het kan dan onmogelijk de bedoeling zijn geweest van Jeremia om dat Nieuwe Verbond in tegenstelling te zien met de Davidische gestalte van het Mozaische verbond: Jeremia 30-31 is een hecht gestructureerde literaire eenheid (Wessels, 1987). In het Nieuwe Verbond zal het Mozaische verbond in zijn Davidische gestalte vernieuwd in eschatologisch-messiaanse zin worden voortgezet.

Toch lijkt het er wel op dat het in Jeremia 31:31 e.v. om een tegenstelling gaat tussen het Nieuwe Verbond en dat met de vaderen gesloten, dat Israel verbroken heeft. Jeremia benadrukt in zijn historische situatie de vergeving van de zonden en het geschreven zijn van de wet in het hart van Israel als aanduiding van het Nieuwe Verbond. In deze konkrete situatie moet het nieuwe van het Nieuwe Verbond worden bezien zonder dat het gecontrasteerd wordt met wat dan nieuwtestamentisch het Oude Verbond wordt genoemd. Want we hebben al gezien dat er geen feitelijk verschil aan te wijzen valt tussen de verschillende verbondsfasen op deze twee punten. Wat wel genoteerd kan worden (zie Rendtorff, 1991:185 e.v.; Schenker, 1993:107 e.v.) is dat het Nieuwe Verbond volgens Jeremia onverbrekelijk zal zijn (Hafemann, 1997:31-33). De onwankelbaarheid van het Nieuwe Verbond wordt onderstreept door het Noachitische karakter ervan (Wielenga, 1996b). Ook in Jeremia 30-31 wordt er een relatie gelegd tussen de onderhouding van de schepping en de voortduur van het verbond. Het nieuwe is 
dat Israel het verbond zal gaan houden: de wet en de vergeving verwijzen daar naar, al werkt Jeremia zelf het niet nader uit; dat gebeurt in Ezechiel en in met name Deutero-Jesaja. Wel moet bedacht worden dat Jeremia 30:7 het heeft over een overblijfsel van Israel, de Rest, aan wie het beloofde heil ten deel zal vallen en in staat zal worden gesteld het verbond te houden. Door het oordeel heen zal de nieuwe heilstoestand er komen. Kortom, wij delen de conclusie van Schenker (1993:112): "Der neue Bund ist der alte, aber der gegen den Bruch gefeite Bund."

\subsection{Het Nieuwe Verbond bij Ezechiel}

Bij Ezechiel komt duidelijker uit de verf hoe Israel in staat zal zijn de wet te houden: de Geest wordt toegezegd. Hier is sprake van de Geest als gehypostaseerde Persoon en niet als kracht van God, zoals meestal in het Oude Testament het geval is (Westermann, 1981). Door de Geest zal Israel tot leven gewekt worden en tot wetsgehoorzaamheid in staat worden gesteld (Ezechiel 3637; zie Jüngling, 1993:113-148), want het is Hij die het hart, de werkplaats van de Geest, zal transformeren (11:17-20, 20:33-40; zie Dijkstra, 1986:107 e.v.). Hoe sterk het genadekarakter van het Nieuwe Verbond moet worden beklemtoond, kan blijken uit de nadruk die Ezechiel legt op het handelen van God "terwille van zijn naam" (20:14 e.v.) voor de ogen der volkeren (16:35-43, 36:2122) de verbondsgeschiedenis door. Maar daarom zal dan ook de nieuwe heilstijd realiteit worden (zie ook 16:59-63). Ook bij Ezechiel komt de vergeving en het nieuwe hart voor als cruciaal voor de beloofde toekomst (36:25 e.v.) maar in onlosmakelijk verband dus met de Geest (36:27), die continu op het volk zal komen te rusten (Van Bruggen, 1996:201; Scheepers, 1960:148 e.v.). Het nieuwe van het Nieuwe Verbond is volgens Ezechiel de gave van de Geest, zodat het verbond ook van Israels kant gehouden kan worden.

\subsection{Het Nieuwe Verbond in Deutero-Jesaja}

We gaan niet in op de inleidingsvragen die de compositie van het Jesaja-boek betreffen (zie Koole, 1995); we gebruiken verder gemakshalve de aanduiding II en III Jesaja. Er is al vaker gewezen op overeenkomsten tussen Ezechiel en II Jesaja (Renkema, 1978:41 e.v.). Toch speelt bij eerste lezing het Nieuwe Verbond in II Jesaja niet of nauwelijks een rol. Nader onderzoek echter niet alleen in die plaatsen waar de term verbond wel voorkomt (42:6), maar ook waar gesproken wordt over de vroegere en nieuwe dingen $(42: 9-10 ; 43: 19 ; 48: 6)$, levert vruchten af voor een evenwichtig oordeel over de boodschap van II Jesaja over het Nieuwe Verbond, dat aansluit bij wat we al vonden bij Jeremia en Ezechiel, en waarbij in het Nieuwe Testament wordt aangesloten. We menen dat de nieuwe dingen betrekking hebben op het heil dat de Knecht des Heere zal bewerken; zoals bekend, wordt in het Nieuwe Testament deze Knecht met Jezus Christus gelijkgesteld (Koole, 1990; 1995). 
Het is niet mogelijk in te gaan op de problematiek rond de Knecht in het oudtestamentische onderzoek (zie Beuken, 1983; Koole, 1990; 1995). Met name over de vraag of met de Knecht Israel wordt bedoeld of een messiaanse figuur van de eindtijd, blijft het debat onbeslist. Niet zo zeer de persoon als wel het werk van de Knecht wordt benadrukt. Wij gaan ervan uit dat de Knecht Israel vertegenwoordigt en in haar plaats volbrengt wat God van haar in het kader van het verbond verwachtte. Vandaar waarschijnlijk dat niet altijd tussen de Knecht als Israel en als messiaanse eindtijdfiguur onderscheiden kan worden. Maar wij zien geen doorslaggevende argumenten om de oudchristelijke messiaanse uitleg van de Knechtsliederen af te wijzen.

Het gaat in de nieuwe dingen om zaken die tot dan toe nog niet door God bekend gemaakt waren (48:7). De vroegere dingen als de uittocht uit Egypte of de terugkeer uit ballingschap naar Jerusalem waren al wel bekend. De nieuwe dingen zullen een totaal onverwachte wending geven aan de geschiedenis van God met zijn volk met een perspectief dat de hele wereld omvat. Het nieuwe ervan is niet dat de volkeren in het heil van Israel zullen delen; dat was van meet af aan de bedoeling. Met Koole (1985:165 e.v.) zijn we van mening dat het nieuwe is dat God zelf deze nieuwe wending naar het heil zal volbrengen door zijn met de Geest begaafde (Jesaja 11:1 e.v.) Knecht. Het nieuwe is het verbond dat deze Knecht als licht der wereld zal realiseren (42:6), waarbij we bedenken dat volgens Jesaja 53 hij dat zal bewerken door lijden heen, wat we in overeenstemming met de oudchristelijke traditie als plaatsvervangend lijden willen typeren (Koole, 1990:88 e.v., 203 e.v.; vgl. ook Jesaja 50:4 e.v.). Vergeten we niet dat ook dit lijden tot de nieuwe dingen behoort, dat tot dan toe onbekend was aan Israel (Jesaja 52:13-15), en waar ook de wereld der volkeren zich over verbazen zal. De nieuwe heilssituatie van het Nieuwe Verbond wat God zal laten aanbreken door het lijden van de Knecht heen, te beginnen met de terugkeer uit ballingschap (Jesaja 54-55; 60-63), kan dan ook niet meer tegengehouden worden. Het werk van de Knecht in zijn lijden opent de weg naar de beloofde toekomst. De droom van een onverbrekelijk verbond van Israels kant kan nu op grond van het plaatsvervangend lijden van de Knecht verwerkelijkt worden. De belofte van de Geest wordt dan ook door hem ingelost aan Israel en de volkeren.

\subsection{Voorlopige conclusie}

We hebben geen ruimte om Jesaja 54:10 en 55:3 te bespreken (Koole, 1990:317 e.v.). Duidelijk wordt wel dat ook het Nieuwe Verbond voorwaardelijk is, zij het dat het door de komst van de Knecht in samenhang met de Geest alleen mogelijk is het verbond te onderhouden. De bekende dogmatische stelling dat het verbond bilateraal is in haar voortbestaan, geldt ook van het Nieuwe Verbond, zoals er in het Oude Testament over gesproken wordt. We laten nu verder III Jesaja rusten, waar de zaak, waar het Nieuwe Verbond voor staat, op duidelijke wijze wordt 
uitgetekend. Ook het werk van de Knecht is beslissend voor de verwerkelijking van de heilsbeloften in dit deel van Jesaja. We willen ons oudtestamentische onderzoek echter afsluiten met de conclusie dat het Nieuwe Verbond in het Oude Testament niet anders is dan het totaal vernieuwde Mozaische verbond, dat zijn oorsprong heeft in de dagen van Adam, Noach en Abraham. Er is sprake van discontinuiteit: het nieuwe is ongekend en ongedacht. Maar de discontinuiteit staat in dienst van de continuiteit. De krisis van het verbond had dergelijke proporties aangenomen dat een verstommend nieuw initiatief door God werd aangekondigd. Ten spijte van al de contingentie in de verbondsgeschiedenis, is de coherentie doorslaggevend. In het nieuwe is het vroegere helemaal aanwezig zij het op radikaal nieuwe wijze; vanuit het nieuwe komt er ook een nieuw perspectief op het vroegere of oude. Juist in het Nieuwe Testament krijgen we daar zicht op.

\section{Het Oude Verbond in het Nieuwe Testament}

Het zou de moeite waard zijn in te gaan op allerlei hermeneutische vragen de witleg van het Oude in het Nieuwe Testament betreffend (zie Mulder, 1983; Childs, 1993). We volstaan met de opmerking dat men het Nieuwe Testament niet als een moderne commentaar op het Oude Testament kan hanteren. Het is voor modeme lezers van de Bijbel niet altijd zo duidelijk hoe precies iedere nieuwtestamentische auteur gebruik gemaakt heeft van het Oude Testament (Berkhof, 1993:225 e.v.). Dat de oudtestamentische Schrift gezag voor hen had, is buiten kijf; en dat ze steeds die Schrift lazen vanuit hun ontmoeting met Jezus van Nasareth als de Christus, de Zoon van God, moet hermeneutisch van doorslaggevende betekenis geacht worden voor ons eigen verstaan van de Schrift van Oude en Nieuwe Testament. We beperken ons vanwege de ruimte tot wat we in Hebreeên lezen over het Oude en Nieuwe Verbond, en ook dan nog beperken we ons tot het uiterste. We verkeren in de gelukkige omstandigheid gebruik te kunnen maken van de nog altijd leerzame studie van De Vuyst (1964); we sluiten ons in ons onderzoek bij hem aan.

\subsection{Inleidende opmerkingen}

In het modernere onderzoek is er min of meer overeenstemming dat Hebreeen veeleer een leerrede is, die zich richt tegen dwalingen van christenen van de tweede of derde generatie, die terug dreigden te vallen in bepaalde vormen van de Joodse religie, waarin ook engelenspeculaties een rol speelden (Vanhoye, 1973; Andriessen \& Lenglet, 1971). De lijnen van het Oude Testament worden dan ook in deze kontekst zwaar aangezet in de Brief. Tegelijk wordt er een tegenstelling opgemerkt tussen wat de Brief leert over het Oude en Nieuwe Verbond en wat we in Jeremia 31:31 e.v. gelezen hebben. Onder andere Luz (1967) en Lehne (1990) hebben die tegenstelling tussen Oud en Nieuw Verbond in de Brief benadrukt, waarmee zij in strijd zou komen met wat er in het Oude Testament 
zelf over geschreven is. Lehne (1990:53) meent dat volgens de Brief het Oude Verbond structureel ontoereikend was en vanwege de gebrekkige cultus ineffectief. Dacht men in Qumran nog dat het Oude Verbond te vernieuwen was, in de Brief is deze hoop opgegeven (Lehne, 1990:43 e.v.). Het Oude moest door een totaal Nieuw Verbond vervangen worden. De Brief zou hierin ook radikaler zijn geweest dan Paulus in bij voorbeeld Romeinen 9-11. Het gebruik dat de Brief maakt van de metafoor Nieuw Verbond heeft inhoudelijk weinig meer te maken met waar Jeremia het over had. Dat deze visie gevolgen heeft voor de coherentie van de verbondsgeschiedenis hoeft nu verder geen betoog. Ook anderen benadrukken de discontinuiteit tussen Jeremia en Hebreeên sterker dan wij aanvaardbaar achten (zo König, 1987:94 e.v.; 1995:48). Het Nieuwe Verbond is dan dat met Abraham, het Oude is het Mozaïsche dat dan als een tijdelijke bedeling achterhaald is geworden. In het Oude Testament vonden wij geen bewijs voor deze gedachte. De vraag is nu of wij in deze Brief er wèl gronden voor vinden.

\subsection{Hebreeën 8}

Vanaf hoofdstuk 7 lijkt er inderdaad een tegenstelling gemaakt te worden tussen Oud en Nieuw Verbond. Maar bedacht moet worden dat vrijwel uitsluitend het cultische aspect van het verbond ter sprake wordt gebracht. Dát was in geding in die situatie; we ontvangen ook in deze leerrede geen locus de foedere in de zin van de gereformeerde schooltraditie. Verder moet rekening gehouden worden met de uiterst positieve toon waarop gesproken wordt over de oudtestamentische offerdienst; daar wordt niet minachtend of neerbuigend over geschreven - in tegendeel! God zelf heeft deze cultus ingesteld tot verzoening van zonden, wat geheel overeenstemt met wat in het Oude Testament zelf erover geschreven is. $\mathrm{Na}$ de zonde met het gouden kalf was er op geen andere manier gemeenschap met God mogelijk dan in de cultus door middel van de Levitische priesterschap. Dat deze cultus toch niet permanent de krisis waarin zij samen met het verbond terecht was gekomen, kon overwinnen, moet op rekening van de zonden van Israel geschreven worden. Daarom was er een verandering van priesterschap nodig en een voor altijd afdoend offer. En hier brengt de Brief dan Christus als de hogepriester naar de orde van Melchizedek ter sprake, die het volmaakte offer bracht, zodat de krisis van het verbond overwonnen werd, en de beloofde toekomst bereikt. Daarom was het verbond dat Christus vertegenwoordigde, beter, effectiever (De Vuyst, 1964:100 e.v.). Het verschil tussen beide verbonden, dat vertegenwoordigd door Mozes en dat door Christus, zit niet in de beloften (vgl. Exodus 24:8 en Hebreeên 8:6) maar enkel en alleen in de verbondsmiddelaar, Jezus Christus. Vanuit de ontmoeting met hem bekeken, kan alleen maar gesteld worden dat het Nieuwe Verbond beter is dan het Oude (De Vuyst, 1964:107 e.v.). Jezus was meer dan Mozes, die verre van volmaakt was, zoals in Deuteronomium uitvoerig wordt gedocumenteerd; hij kon dan ook niet voor de zonde van het volk sterven om de zonde met het gouden kalf uit te delgen 
(Exodus 32:32); en Jezus was zeker de meerdere van Aaron, die de zonde met het gouden kalf faciliteerde. Het betere is geheel en al aan Christus vastgemaakt. Vanuit hem bekeken, kan gezien worden waarom en waarin het Nieuwe Verbond het betere was. Vanuit hem valt er nieuw licht op het oude, wat voorafging aan zijn komst.

Ook als het Oude Verbond als "niet onberispelijk" wordt getekend (8:7), kan dat niet als een diskwalificatie gezien worden (De Vuyst, 1964:115 e.v.). Terugblikkend kan gezegd worden dat er iets onvoldaans aan het Oude Verbond zat dat trouwens nergens tot het Mozaische beperkt wordt in de Brief; alle andere fasen voordat Christus kwam, zijn erin begrepen; de naam van Mozes staat voor de hele oude bedeling. Ondanks alle dankbaarheid voor verbond en cultus moest toch worden vastgesteld dat het krachtige niet krachtig genoeg gebleken is om de gemeenschap met God in stand te houden. Zowel in Jeremia 31 als in de Brief wordt dat op rekening geschreven van het volk dat zondigde, waar ook Paulus zich trouwens bij zou hebben kunnen aansluiten - gezien zijn spreken over de wet van Mozes. Over de vraag hoe het kwam dat het krachtige niet krachtiger en effectiever was, wordt niet gespeculeerd. Het wordt vanuit de komst van Christus geconstateerd. Maar het wordt niet op konto van het verbond als zodanig geschreven, als zou dat structureel gebrekkig van karakter zijn geweest.

\subsection{Het Jeremia-citaat}

Uit Hebreeën 8 kan niet worden opgemaakt dat Jeremia 31 totaal tegen haar oorspronkelijke bedoeling in gebruikt werd. Wij menen dat de profetie inderdaad tot haar recht komt in de Brief, zeker als we Jeremia niet isoleren uit het geheel van de profetische tradities waarin hij stond en gefunctioneerd heef. Het nieuwe dat de oudtestamentische profetie heeft aangekondigd, is gekomen in Christus. Met een beroep op de gezaghebbende Schrift wordt vanuit zijn komst gezien wat er ontbrak aan de eerst komende verbondsbedeling, en wat er met hem voor in de plaats gekomen is. Het nieuwe is in hoofdstuk 8 (zie ook 10:16 e.v.) niet dat het verbond andersoortig is geworden, maar dat nu gekomen is waarop gehoopt werd krachtens de profetie (De Vuyst, 1964:122). Ondanks de ontrouw van Juda en Israel(!) komt er heil dankzij Gods trouw aan zijn beloften vanouds. Het Oude Verbond werd niet ontbonden en vervangen met een totaal ander verbond; het werd radikaal vernieuwd op een totaal ongedachte en ongekende wijze, zoals door de profetie al aangekondigd. Gods genade overwon!

Gevolg van Gods definitieve ingrijpen in de verbondsgeschiedenis door Christus is dat thans Israel niet meer om de wet heen kan en heen wil, zoals in de dagen van Jeremia. Van nu af aan zal de wet het orientatiepunt van Gods volk zijn: het verbond zal voluit bilateraal functioneren. Door de werking van de Geest en op grond van het werk van de hogepriester Christus (8:10c) zal de wet van harte onderhouden worden als leefregel der dankbaarheid. Het zal een tijd zijn van 
Woordvolheid in tegenstelling met de Woordleegheid in de tijd van de ballingschap (8:11). God heeft finaal gesproken in zijn Zoon (1:1 e.v.), zodat de wereld God kan kennen zó zoals Hij werkelijk is: een God die zonden vergeeft - geheel in overeenstemming met de profetie in Jeremia 31. Christus is het verschil tussen Oud en Nieuw Verbond (De Vuyst, 1964:167 e.v.). En daarom is terugval in de Joodse religie gevaarlijke dwaasheid: men verspeelt zo de verzoening en de vergeving (9:15; zie König, 1995:52 e.v.). Het beloofde zou men er door mislopen. Waar het om ging, juist in het Oude Verbond, zou dan niet kunnen worden ontvangen.

Uit 10:15 e.v. blijkt wel dat er voor de Brief geen tegenstelling bestond met Jeremia. Het is de Geest die door Jeremia sprak. In de contingente situatie van de geadresseerden was het accent op het definitieve dat met Christus gekomen was, noodzakelijk. Daardoor ontstaat de indruk dat hij Oud en Nieuw contrasteert. In werkelijkheid beschrijft hij binnen de ene verbondsgeschiedenis een bepaald moment contrasterend, dat van de cultus. Het betere verbond is geen ander verbond; we zullen de comparativus serieus dienen te nemen. Dat geldt ook ten aanzien van de verbondssancties: de straffen zijn ook zwaarder dan onder de oude bedeling (10:29). Zelfs de onmogelijke mogelijkheid van verbreking van dit als eeuwig (13:20) beschreven verbond moet dus ernstig genomen worden. Ook terzake van de bilaterale conditionaliteit is er coherentie in de verbondsgeschiedenis, die niet vanuit een predestinatiaans gedetermineerde dogmatiek mag worden opgeheven. Aan dit gevaar is de Gereformeerde Orthodoxie niet altijd ontkomen (Graafland, 1987; 1992; zie ook Verboom, 1996). We vallen dus de hoofdstelling van de gereformeerde dogmatiek bij: het verbond is een werkelijke relatie in de geschiedenis tussen God en mens, door Hem eenzijdig tot stand gebracht, maar door Hem tweezijdig in stand gehouden. Maar het in de geschiedenis moet het volle accent ontvangen: in de geschiedenis zijn contingentie en coherentie van het verbond onlosmakelijk met elkaar verweven. Het gaat in de contingentie om de coherentie!

\section{Geciteerde literatuur}

ANDRIESSEN, P. \& LENGLET, A 1971. De brief aan de Hebreeen Roermond : Romen.

BALKE, W. 1973. Calvijn en de doperse radikalen. Amsterdam: Ton Bolland.

BEKER, J.C. 1980. Paul the apostle. The triumph of God in life and thought. Philadelphia Fortress Press.

BERKHOF, H. 1993. Christelijk geloof. Nijkerk : Callenbach (7e druk)

BEUKEN, W.A M. 1983. Jesaja II b (POT) Nijkerk : Callenbach

CHILDS, B.S. 1993 Biblical theology of the Old and New Testaments: theological reflection on the Christian Bible London : SCM.

DE GRAAF, S.G. 1954. Het ware geloof. Kampen : Kok.

DE GREEF, W. 1996. Getekend voor het leven - over de Heilige Doop (In Van den Brink, G. e.a red. Gegrond geloof. Kempunten uit de geloofsleer in bijbels, historisch en belijdend perspektief. Zoetermeer : Boekencentrum. p. 435-470)

DE VUYST, J. 1964. 'Oud en Nieuw Verbond' in de brief aan de Hebreeen. Kampen : Kok 
DOHMEN, C. 1993. Der Sinaibund als Neuer Bund nach Ex. 19-24. (In Zenger, E. Der Neuen Bund im Alten. Zur Bundestheologie in der beide Testamenten. Freibourg : Herder. p. 51-83.)

DIJKSTRA, M. 1986. Ezechiel 1. (Tekst + toelichting). Kampen : Kok

EICHRODT, W. 1957; 1961. Theologie des Alten Testaments 1, 2/3. Stuttgart : Ehrenfried Klotz.

GESE, H. 1977. Zur biblischen Theologie. Alttestamentliche Vortrage. München : Kaiser

GRAAFLAND, C. 1987. Van Calvijn tot Barth. Oorsprong en ontwikkeling van de leer der verkiezing in het gereformeerd Protestantisme. Zoetermeer : Boekencentrum.

GRAAFLAND, C. 1992; 1994; 1996. Van Calvijn tot Comrie Oorsprong en ontwikkeling van de leer van het verbond in het gereformeerd Protestantisme I-II; III-IV, V-VI. Zoetermeer : Boekencentrum.

GUNNEWEG, A.H J. 1960. Sinabund und Davidsbund. Vetus Testamentum, X:335-41.

HAFEMANN, S. 1997. The "Temple of the Spirit" as the inaugural fulfilment of the New Covenant within the Corinthian correspondence. Ex Auditu, 12:29-42.

JÜNGLING, H.W 1993. Eid und Bund im Ezekiel 16-17. (In Zenger, E. red. Der Neuen Bund im Alten. Zur Bundestheologie der beide Testamenten. Freibourg : Herder. p. 113-148.)

KALLUVEETTIL, P. 1982. Declaration and covenant. A comprehensive review of covenant formulae from the Old Testament and the Ancient Near East. Rome : Biblical Institute

KONIG, A. 1987. Die doop as kinderdoop en grootdoop. Pretoria : NGKB.

KÖNIG, A. 1995. Versoening. Goedkoop? Duur? Verniet? Kaapstad : Lux Verbi

KOOLE, J.L. 1985; 1990; 1995. Jesaja IV/1; IL/2; III. (COT) Kampen : Kok.

KOOPMANS, W.T 1990. Joshua 24 as poetic narrative. Sheffield : JSOT.

KRUSE, H. 1985. David's covenant. Vetus Testamentum, 35(2):139-164.

LEENE, H. 1987. De vroegere en de nieuwe dingen bij Deuterojesaja Amsterdam : VU.

LEHNE, S. 1990. The New Covenant in Hebrews Sheffield : JSOT.

LUZ, U. 1967. Der alte und der neue Bund bei Paulus und im Hebrāerbrief. Evangelische Theologie, 27:318-336

MAYES, A D.H. 1978. The rise of Israelite monarchy. Zeitschrift fur die alttestamentlichen Wissenschaft, 90:1-11.

McCARTHY, D.J 1972. Berith in Old Testament and theology. A review of L. Perlitt's Bundestheologie im Alten Testament. Biblica, 53:110-121

McCARTHY, D.J 1978. Treaty and covenant: a study in form in the ancient oriental documents and in the Old Testament. (AnBibl 21A). 2nd ed. Rome : Biblical Institute Press.

McCARTHY, D.J 1985. Institution and narrative. Collected essays. Rome : Biblical Institute Press.

MULDER, M J. 1983. Funktie en uitleg van de Bijbel (Oude Testament) rondom het begin van onze jaartelling. (In Van der Woude, A.S. red. Bijbels Handboek II b. Kampen : Kok. p. 247-277.)

NICHOLSON, E.W 1986. God and his people. Covenant and theology in the Old Testament Oxford : Clarendon Press.

OBERMAN, H.A. 1986 Die Reformation: Von Wittenberg nach Genf. Götingen : Vandenhoeck \& Ruprecht.

OHMANN, H.M. 1988 Een woord gesproken op zijn tijd. Hoe lezen wij Jesaja 1-39. Franeker Van Wijnen.

OOSTERHOFF, B.J. 1972. Hoe lezen wij Genesis 2 en 3? Een hermeneutische studie Kampen : Kok 
RENDTORRF, R. 1991. Kanon und Theologie. Vorarbeiten zu einer Theologie des Alten Testaments. Neukirchen-Vluyn : Neukirchener Verlag.

RENKEMA, J 1978. De verkondiging van het eerste lied van de Knecht (Jes. 42:1-4) (In Koole, J.L. - Fs, De Knecht. Studies rondom Deutero-Jesaja. Kampen : Kok p. 178. 187.)

SCHEEPERS, J H. 1960. De Gees van God en die gees van die mens. Kampen : Kok.

SCHENKER, A 1993. Der nie aufgehobene Bund. Exegetische Beobachtungen zu Jeremia 31:31-34. (In Zenger, E. red. Der Neuen Bund im Alten Freibourg : Herder Verlag p. 85-112.)

VAN BRUGGEN, J. 1996 Het evangelie van Gods zoon Persoon en leer van Jezus volgens de vier evangeliën (CNT 3e serie.) Kampen : Kok

VANHOYE, A 1973. Door het voorhangsel heen Commentaar op de Brief aan de Hebreeen (Van exegese tot verkondiging 12). Boxtel : Katholieke Bijbelstichting.

VAN ROOY, JA. 1996. Hear, Africa! The message of the Old Testament in the African context. (DSP no 27.) Potchefstroom : PU vir CHO.

VERBOOM, W. 1996. Om het eeuwig welbehagen - over verbond en verkiezing (In Van den Brink, G. e.a. red. Gegrond geloof. Kempunten uit de geloofsleer in bijbels, historisch en belijdend perspektief. Zoetermeer : Boekencentrum p 365-400)

VRIEZEN, Th. C. 1966 Hoofdlijnen der theologie van het Oude Testament. Wageningen Veenman. 3e druk.

WESSELS, W.J. 1987. Die boek Jeremia (In Burden, J.J. \& Prinsloo, W.S Tweegesprek met God Kaapstad : Tafelberg. p. 115-149.)

WESTERMANN, C. 1981. Geist im Alten Testament Evangelische Theologie, 41:223-230

WIELENGA, B. 1990. 'Volk van het Land' als missiologisch model: Oude Testament en zending in zuidafrikaanse kontekst. Pretoria : Unisa. (D.Th.-thesis.)

WLELENGA, B. 1994. Zendingshermeneutiek: een inleiding. (In Bouma, J e.a. red Begeleidend schrijven 25 Jaar theologische studie begeleiding. Amsterdam : Buijten \& Schipperhijn p. 224-235.)

WIELENGA, B. 1996a. Israel en de zending in het Oude Testament (In Van Heest, W red. Beminden om der vaadren wil. Over Israel en de zending. Goes: Oosterbaan \& Le Cointre. p. 11-31)

WIELENGA, B. 1996b. Over het vredesverbond als noachitisch verbond Pactum Salutis in Vetere Testamento. In die Skriflig, 30(4):457-469.

WRIGHT, C.J.H. 1983. Living as the people of God. The relevance of Old Testament ethics London : IVP.

ZENGER, E. 1982. Israel am Sinai Analysen und Interpretationen zu Exodus 17-34 Altenberge : CIS Verlag 